Review Article

\title{
The Regulation by Phenolic Compounds of Soil Organic Matter Dynamics under a Changing Environment
}

\author{
Kyungjin Min, ${ }^{1,2}$ Chris Freeman, ${ }^{3}$ Hojeong Kang, ${ }^{1}$ and Sung-Uk Choi ${ }^{1}$ \\ ${ }^{1}$ School of Civil and Environmental Engineering, Yonsei University, Seoul 120-749, Republic of Korea \\ ${ }^{2}$ Department of Ecology and Evolutionary Biology, University of Kansas, Kansas Biological Survey, Lawrence, KS 66047, USA \\ ${ }^{3}$ School of Biological Sciences, University of Wales, Bangor LL57 2UW, UK \\ Correspondence should be addressed to Hojeong Kang; hj_kang@yonsei.ac.kr
}

Received 19 December 2014; Accepted 5 April 2015

Academic Editor: Aiyagari Ramesh

Copyright (C) 2015 Kyungjin Min et al. This is an open access article distributed under the Creative Commons Attribution License, which permits unrestricted use, distribution, and reproduction in any medium, provided the original work is properly cited.

\begin{abstract}
Phenolics are the most abundant plant metabolites and are believed to decompose slowly in soils compared to other soil organic matter (SOM). Thus, they have often been considered as a slow carbon (C) pool in soil dynamics models. Here, however, we review changes in our concept about the turnover rate of phenolics and quantification of different types of phenolics in soils. Also, we synthesize current research on the degradation of phenolics and their regulatory effects on decomposition. Environmental changes, such as elevated $\mathrm{CO}_{2}$, warming, nitrogen $(\mathrm{N})$ deposition, and drought, could influence the production and form of phenolics, leading to a change in SOM dynamics, and thus we also review the fate of phenolics under environmental disturbances. Finally, we propose the use of phenolics as a tool to control rates of SOM decomposition to stabilize organic carbon in ecosystems. Further studies to clarify the role of phenolics in SOM dynamics should include improving quantification methods, elucidating the relationship between phenolics and soil microorganisms, and determining the interactive effects of combinations of environmental changes on the phenolics production and degradation and subsequent impact on SOM processing.
\end{abstract}

\section{Introduction}

Phenolics consist of more than one aromatic ring, bearing one or more hydroxyl functional groups. They originate from plant materials and industrial products/wastes, which enter the soil either as leachates or as particulate matter [1]. Once integrated into the soil, phenolics can control below-ground processes, including SOM decomposition [2-4] and nutrient cycling [5, 6]. Recently, Freeman et al. [7] have suggested that modification of phenolics in peatland has a potential as a geoengineering tool to capture $\mathrm{C}$ in terrestrial ecosystems.

In spite of theses multitude of studies, however, controversies remain on how phenolics decompose in soils, how they modify the rate of SOM decomposition, and how current environmental changes will influence the fate of phenolics in soils. Given that phenolics represent one of the most abundant components in soils $[8,9]$ and that they affect the cycling of key nutrients to plants and soil microorganism [1,9], it is indispensable to investigate the mechanisms by which phenolics influence decomposition biotically and abiotically and the degree to which these mechanisms will vary in response to environmental changes. This review presents current knowledge about phenolics and their role in decomposition under various environmental changes and proposes areas of future research. This review covers the following six areas: (1) various structures and forms of phenolics in soils; (2) how to extract and measure phenolics in soil samples; (3) biodegradation of phenolics; (4) effects of phenolics on SOM decomposition; (5) effects of environmental changes, such as elevated $\mathrm{CO}_{2}$, warming, $\mathrm{N}$ deposition, and drought, on phenolics and decomposition; and (6) suggestions for future phenolics studies.

\section{Structure and Form in Soils}

Naturally, phenolic compounds are widely distributed throughout the plant kingdom, constituting up to $60 \%$ of plant dry mass [10]. Due to its loose definition (presence of at least one aromatic ring and hydroxyl group), more than 8,000 compounds have been classified as phenolics to date [11], encompassing simple, low molecular compounds to complex, 
TABLE 1: Methods to quantify phenolic compounds.

\begin{tabular}{lll}
\hline Assay & Types of phenolics & Description \\
\hline Folin-Ciocalteu assay & Total phenolic acids & $\begin{array}{l}\text { An assay based on electron transfer (ET) in which } \\
\text { oxidation of phenolics by Folin-Cioalteu reagent gives a } \\
\text { colored product at 750 nm }\end{array}$ \\
\hline & $\begin{array}{l}\text { A method in which oxidation of lignin by cupric oxide } \\
\text { yields single-ring phenol compounds (vanillyl-, } \\
\text { syringyl-, and p-coumaryl units), followed by gas } \\
\text { chromatography } \\
\text { Also, the acid to aldehyde ratio can be used to estimate } \\
\text { the state of decomposition of lignin }\end{array}$ \\
& phenolics & $\begin{array}{l}\text { A separation technique in which a mixture of phenolics } \\
\text { produces different retention times depending on their } \\
\text { affinity to the stationary phase }\end{array}$ \\
\hline HPLC & Individual & [13]
\end{tabular}

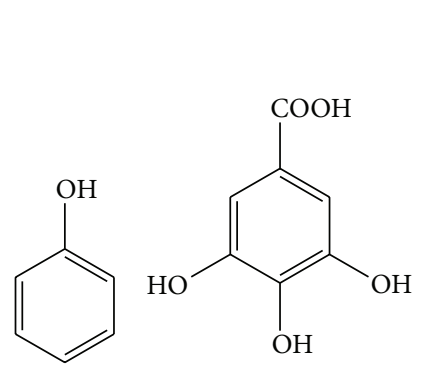

(a)

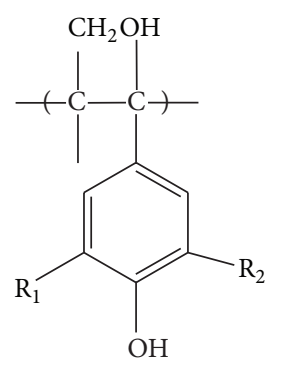

(c)
FIGURE 1: Chemical structures of several phenolics: phenol (a), the simplest structure of phenolic compound, phenolic acid (gallic acid) (b), and tannin (c).

highly polymerized compounds. Often, the number of aromatic rings and chemical structure are used to classify phenolics (Figure 1). For example, phenol, the simplest form of phenolics, has one aromatic ring with no extra carbon and belongs to class simple phenols. Class phenolic acids have a basic structure of C6-C1, including gallic acid, vanillic acid, and syringic acid. Lignin, one of the most common compounds in plants, is categorized as class lignins, exhibiting multiple combination of C6-C3 structure.

Phenolics in soils can exist as (1) a dissolved form, which moves freely in the soil solution, (2) a sorbed form, which reversibly binds to the soil particle or proteins, and (3) a polymerized form, consisting of humic substances (Figure 2). As many phenolics including phenolic acids and tannins are water soluble, they remain in solution between soil particles [15]. Reversible sorption of phenolics by soils occurs through hydrophobic, hydrogen, and ionic bond [8]. Humic substances, a stable polymer in soils, are generated by a polymerization of phenolics with other phenolics or soil organic matter [9].

Recent studies suggest that the form of phenolics, not their chemical structure, can influence their fate in soils [1619], raising a question on conventional classification of phenolics into a slow, recalcitrant pool in $\mathrm{C}$ dynamics climate model [20]. For example, dissolved phenolics may have higher chance than sorbed or polymerized ones to encounter microorganisms in soil solution, allowing them to be processed quickly into simple, assimilable forms. In contrast, physically and chemically protected phenolics can persist longer than dissolved forms, providing feedbacks to SOMdecomposing microorganisms via changing soil $\mathrm{pH}$, nutrient availability, and enzyme activities. Thus, caution is required to investigate the role of phenolics in SOM decomposition.

\section{Extraction and Quantification of Phenolics}

A variety of methods of extraction and quantification of phenolic compounds in soils have been established (Table 1). Solvents such as water, acetone, methanol, and citrate are widely used to extract phenolics. Blum [21] reported that soil samples extracted by water and citrate were suitable for estimating both free phenolic acids and sorbed phenolics. Arditsoglou and Voutsa [22] showed that acetone has higher extraction efficiency than methanol in aqueous samples. In contrast, Mukhopadhyay et al. [23] revealed that a mixture of methanol and water $(6: 4, \mathrm{v} / \mathrm{v})$ was best to extract total phenolics and individual phenolic acids from black cohosh.

As the amount of phenolic compounds in soils can vary, the Folin-Ciocalteu assay is commonly used to determine the total amount of phenolic acids [24-26]. This assay is relatively simple compared to the $\mathrm{CuO}$ oxidation and the HPLC method. Thoss et al. [27] have compared 5 different methods to measure phenolic content in various freshwater samples. They concluded that a different pattern for each site originated from reactivity of phenolic materials and that FolinCiocalteu assay is the most appropriate for measurement of total phenolics. However, Ohno and First [28] pinpointed the limitations of the Folin-Ciocalteu assay that it is suited only for samples extracted by water, and interference by organic matter, such as sugars and aromatic amines, makes it impossible to precisely measure the amount of phenolic acids in citrate-extracted soils. In addition, the Folin-Ciocalteu assay was criticized for its low sensitivity [21].

Prior et al. [36] suggested correcting for nonphenolic compounds by using gallic acid as a reference for standardization. For quantification of highly polymerized lignin, gas chromatography (GC) followed by $\mathrm{CuO}$ oxidation is 
TABLE 2: Extracellular enzymes involved in phenolics degradation in soils.

\begin{tabular}{|c|c|c|c|c|}
\hline \multirow{2}{*}{ Enzyme } & \multirow{2}{*}{ Microorganism } & \multicolumn{2}{|c|}{ Optimum condition } & \multirow{2}{*}{ Reference } \\
\hline & & $\mathrm{pH}$ & Temperature & \\
\hline \multirow{2}{*}{ Lignin peroxidase } & Phanerochaete chrysosporium & 2.5 & & {$[29]$} \\
\hline & Phanerochaete chrysosporium & 4.2 & 34 & {$[30]$} \\
\hline \multirow[t]{2}{*}{ Manganese peroxidase } & Phanerochaete chrysosporium & 4.5 & 32 & $\begin{array}{l}{[31]} \\
{[30]}\end{array}$ \\
\hline & Phanerochaete sordida & $4.5 \sim 5.0$ & & {$[32]$} \\
\hline \multirow{3}{*}{ Laccase } & Trametes versicolor & 2.0 & & [29] \\
\hline & Basidiomycete PM1 & 4.5 & 80 & {$[33]$} \\
\hline & Pycnoporus sanguineus & $3 \sim 5$ & 55 & {$[34]$} \\
\hline Phenol oxidase & Termitomyces albuminosus & 2.3 & & {$[35]$} \\
\hline
\end{tabular}

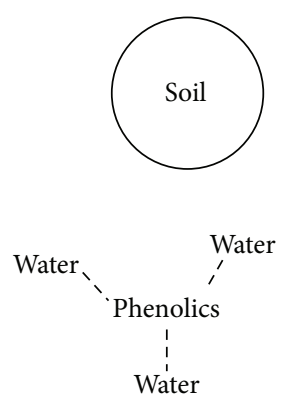

(a)

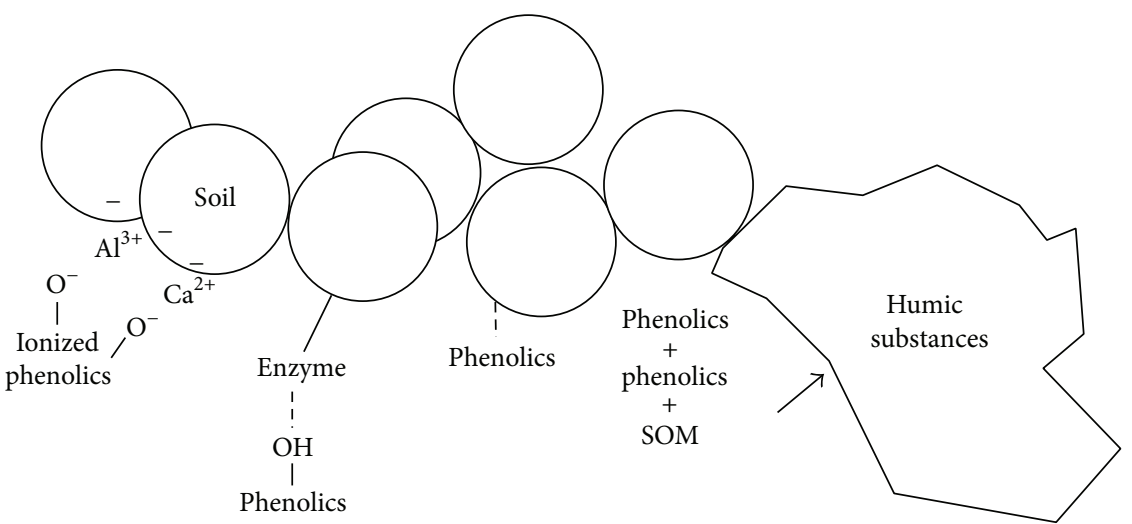

(b)

(c)

FIGURE 2: Various forms of phenolic compounds in soils. A dissolved form (a) where phenolics make multiple hydrogen bonds with water molecules surrounding them. A sorbed form (b) where phenolics are absorbed in soils and may detach from them reversibly through ionic, hydrogen, and hydrophobic bonds. A polymerized form (c) where phenolics consist of humic substances connected with other soil organic matter.

employed $[37,38] . \mathrm{CuO}$ oxidation has the potential to be a powerful tool to estimate lignin content in soils as well as the degree of lignin decomposition [39]. Even though GC yields a high sensitivity, the low volatility of simple phenolic compounds requires a derivatization step, resulting in longer sample preparation [40]. Over recent decades, analysis of phenolics has been conducted via high performance liquid chromatography (HPLC) [41-44]. However, wide use of HPLC in ecological studies has been restricted by high cost and complicated process of operation.

\section{Degradation of Phenolics}

In soils, phenolics are mainly degraded by fungi (e.g., Basidiomycetes and Ascomycetes) and bacteria (e.g., Pseudomonas). These microorganisms release extracellular enzymes into soils that break down phenolic compounds (Table 2). Phenolics-degrading enzymes are often named as phenol oxidase or peroxidase, according to their electron acceptor [45]. Both enzymes cause nonspecific oxidation of phenolic compounds, consuming oxygen and hydrogen peroxide as an electron acceptor, respectively.
Environmental factors, such as soil $\mathrm{pH}$, temperature, oxygen, and substrate, can affect the degradation of phenolics. Contrary to the relatively low optimal $\mathrm{pH}$ of purified enzymes in laboratory conditions (Table 2), Sinsabaugh [45] found that there is a positive relationship between phenolicsdegrading enzyme activities and soil $\mathrm{pH}$ across ecosystems. Likewise, Pind et al. [24] have reported that phenol oxidase activity increases as $\mathrm{pH}$ of peat soils increases. Regarding temperature, phenol oxidase showed no clear relationship [46-48] in the field conditions probably due to the interactive effecs of oxygen availability at different temperatures. However, purified phenol oxidase increased its decay of L-DOPA, a proxy of phenolics in lab conditions, at a temperatture of $5-25^{\circ} \mathrm{C}$ [49]. As phenol oxidase uses oxygen as an electron acceptor, its activity is proportional to oxygen concentration [24]. The relationship between the activity of phenol oxidase and phenolics concentration in natural ecosystem is not clear, as conflicting evidence is currently present. While some studies reported a positive relationship [2,38, 50,51], still others demonstrated contradictory results, reporting a negative or inverse relationship $[25,52-54]$ or no relationship $[55,56]$. 


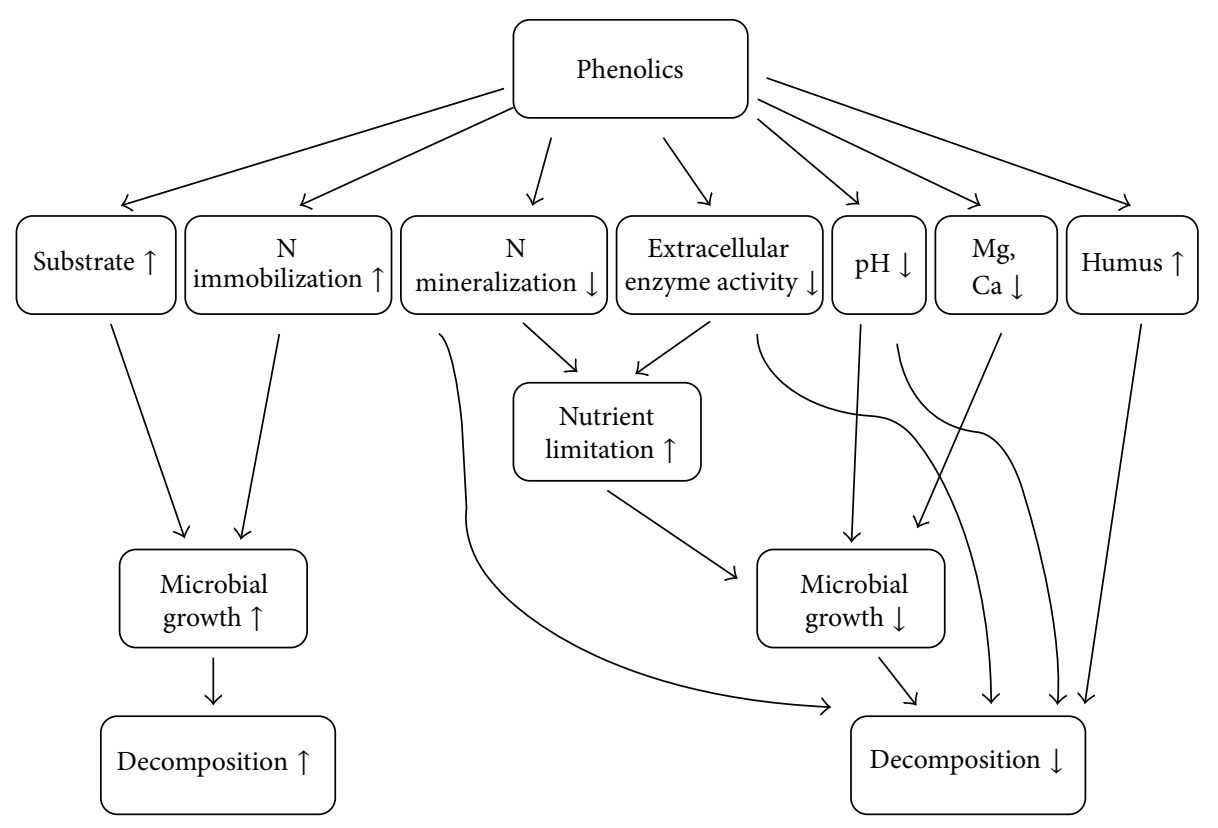

FIGURE 3: Effects of phenolics on the rate of soil organic matter decomposition.

Such diverse responses, however, should be interpreted with care. In case of soil systems with a large amount of phenolics such as peat matrix, higher phenol oxidase in soil results in higher phenolic content in pore water as a product of enzyme action on peat, resulting in a positive relationship between phenol oxidase and phenolics. However, if correlation analysis was conducted between phenol oxidase in soils and phenolics in soil matrix or soil extract in mineral soils such forest soils, a negative correlation has often been reported because here phenolics may represent an enzyme substrate rather than a product. Another possibility is the dual functions of phenol oxidase. For example, Burke and Cairney [57] pointed out that mycorrhizal laccases can mediate both in depolymerization and polymerization and that, without the knowledge of redox mediators for these enzymes, predicting the direction of phenolics processing may be difficult.

Degradation of phenolics is usually reported by several groups to be slower than the degradation of other SOM fractions. The litter bag experiment demonstrated that labile compounds in litter such as carbohydrates and proteins were preferentially decomposed over phenolic compounds $[3,58]$. As such, phenolic concentrations have been useful in predicting the rate of litter degradation $[59,60]$. Yet, as stated above in Section 2, phenolics can decompose fast in certain conditions. Soluble phenolics and tannins degraded to $36 \sim 50 \%$ of the initial content in the litter bag experiment [61, 62]. Degradation of lignin, determined by the acid to aldehyde ratioin $\mathrm{CuO}$ oxidation products (see Table 1), was dominant over degradation of other SOM in forest soils [63].

${ }^{14} \mathrm{C}$-labelling revealed that 56 68\% of lignin from maize was transformed into $\mathrm{CO}_{2}$ during 6 months of a laboratory incubation [64].

\section{Effects of Phenolics on Other SOM Decomposition}

Effects of phenolics on SOM decomposition have been studied directly (i.e., litter bag) or indirectly (i.e., microbial biomass, extracellular enzyme activity, and heterotrophic respiration). Generally, phenolics reduced the rate of litter/SOM decomposition [65, 66]. Moreover, phenolic acids released by Sphagnum in peatlands suppressed bacterial and fungal growth $[67,68]$. Even low concentrations of phenolics in peat homogenates have been noted to inhibit the activity of $\beta$ glucosidase, phosphatase, sulphatase, chitinase, and xylosidase by $21,15,32,18$, and $14 \%$, respectively [69]. In addition, dissolved organic matter containing phenolic compounds from peat samples decreased $\mathrm{CO}_{2}$ production in anaerobic conditions [70]. Likewise, the rate of litter decomposition was shown to be inversely proportional to the phenolic content in litter [61].

As illustrated in Figure 3, the inhibition of decomposition by phenolics can occur via (1) formation of covalent bonds with proteins, decreasing $\mathrm{N}$ mineralization and enhancing $\mathrm{N}$ limitation to microorganisms [71], (2) oxidation of other phenolics, leading to humus formation [72], (3) suppression of microbial growth by lowering $\mathrm{pH}$ [73], (4) deprivation of metal ions by their high cation-exchange capacity [74], or (5) a formation of phenolic-enzyme complex, inactivating decomposition activity [75]. Yet, there are several studies beyond this simple negative relationship between phenolics and decomposition. Fierer et al. [76] found out that low molecular phenolic compounds and some tannins could serve as a labile substrate, promoting microbial biomass. Müller et al. [77] showed that lignin-derived phenolic compounds induced cellulase production, suggesting their 
potential to enhance decomposition. Significant reduction in SOM content was also observed after phenolics were added [78]. In agreement with this finding, phenolic concentrations have been reported to be positively correlated to $\mathrm{CO}_{2}$ release from soil [79] or litter [66].

Opposing reviews on the effect of phenolics on SOM decomposition argue further studies on the relationship between the forms and the roles of phenolics on decomposition and clearer terminology, as a wide range of molecules are defined as phenolics. In general, simple phenolics, such as phenolic acids, appear to increase decomposition, while complex phenolics decrease decomposition. Hoostal and Bouzat [80] showed that microbial extracellular enzyme activities were dependent on the source and composition of phenolics, rather than the absolute quantities of phenolics.

\section{Effects of Environmental Changes on Phenolics}

So far, several studies have aimed at elucidating how environmental changes such as elevated $\mathrm{CO}_{2}$, warming, $\mathrm{N}$ deposition, and drought may affect phenolic production from plant tissues, subsequent degradation in soils, and SOM decomposition.

Elevated $\mathrm{CO}_{2}$ usually increases phenolic concentrations in plants (Table 3 ). In field $\mathrm{CO}_{2}$ enrichment experiments, phenolic compounds in plant tissues, such as leaves, needles, stems, and rhizomes, increased by 11-182\% [81-84]. Elevated $\mathrm{CO}_{2}$ can increase carbon supply and nutrient (e.g., $\mathrm{N}$ ) stress in trees, resulting in decreased carbon demand. Such change is known to accelerate the accumulation of total nonstructural carbohydrates and the synthesis of carbonbased secondary or structural compounds [81]. Change in the concentration of phenolics from plant tissues may impart its effect on downstream processes including SOM decomposition. For example, Siegenthaler et al. [58] found that elevated $\mathrm{CO}_{2}$ induced a production of phenolic-rich litters, resulting in declining SOM decomposition. Effects of elevated $\mathrm{CO}_{2}$ on phenolic production in wetlands including peatlands have been extensively studied because wetlands are one of the key sources of DOC and phenolics to aquatic ecosystems. For example, elevated $\mathrm{CO}_{2}$ increased DOC and phenolic leaching from wetlands $[69,85]$, which may decrease hydrolase activities [2]. However, some studies have reported a faster degradation of phenolics at elevated $\mathrm{CO}_{2}$. After 559 days of litter bag incubation, lignin loss from Mongolian oak fine roots was $13 \%$ faster in the elevated $\mathrm{CO}_{2}$ chamber than in the ambient chamber, which was attributed to a $10 \%$ increase in phenol oxidase activity compared to the control nontreated group [86]. Moreover, phenolic compounds in an ombrotrophic bog decreased by $15.4 \%$ at elevated $\mathrm{CO}_{2}$ compared to control [87], suggesting that elevated $\mathrm{CO}_{2}$ may accelerate phenolic degradation. It appears that elevated $\mathrm{CO}_{2}$ often increases the total amount of carbon supplied to belowground microorganisms and may induce "priming" effects to accelerate the decomposition of old or recalcitrant organic matter. Norby et al. [88] studied the effects of elevated $\mathrm{CO}_{2}$ on litter chemistry and decomposition rates in upland vegetation and demonstrated that elevated $\mathrm{CO}_{2}$ does increase lignin content in leaf litter significantly, but there is no significant effect on decomposition rate. In summary, further investigation is warranted on the effects of increasing phenolics on decomposition because of the involvement of other factors such as vegetation types, ecosystem types, nutrient availability, and changes in other factors (e.g., temperature and water availability).

Rising temperature is expected to be accompanied by an increase in atmospheric $\mathrm{CO}_{2}$ concentration. Few studies have measured the effect of warming on phenolic production and degradation, with an emphasis on whole organic matter decomposition. Unlike the rather unidirectional influences of elevated $\mathrm{CO}_{2}$, warming has various effects on the production of phenolics (Table 3). Increases in temperature have led to both an increase [89] and a decrease [90] in phenolic production. Warmer conditions usually accelerate biochemical reactions and may result in lowering production of secondary metabolites because plant growth would be enhanced. In fact, Zvereva and Kozlov [91] have reported lower phenolic contents under warming conditions than control in their meta-analysis. However, interactive or simultaneous effects of elevated $\mathrm{CO}_{2}$ and warming in relation to phenolics production have not been reported $[83,90]$ because two effects often negate each other [91].

$\mathrm{N}$ enrichment was studied in terms of atmospheric $\mathrm{N}$ deposition and fertilizer additions. Many studies suggest that phenolic concentrations are unchanged after $\mathrm{N}$ enrichment [92-94]. Extracellular enzymes, such as phenol oxidase and peroxidase, have been widely used for estimating the rates of phenolic degradation and SOM decomposition with $\mathrm{N}$ additions. Often, $\mathrm{N}$ enrichment decreases phenol oxidase $[85,95]$, while hydrolases are often activated. Sinsabaugh [45] reviewed that responses of phenol oxidase to $\mathrm{N}$ enrichment can differ by the types of ecosystem determined, as it decreases its activity in the forest and increases it in grassland or agricultural system. These contrasting results may originate from the initial lignocellulose contents in litter. In contrast, Bragazza et al. [96] have reported that $\mathrm{N}$ deposition can accelerate carbon release from peat bogs by activating phenol oxidase.

Global climate change models often predict increases in frequency and intensity of drought. Such changes can affect water availability in terrestrial ecosystems and water levels in wetlands. In wetlands, the effects of drought on nutrient cycling have drew much attention due to their close association with water. Most studies reported that drought increases the activity of phenol oxidase, implying stimulated decomposition [87, 97-99]. On the other hand, reduction in phenol oxidase activity was also found in peatland and heathland in response to simulated drought $[4,100]$. Toberman et al. [100] suggested that initial water content in soils may be responsible for these contrasting responses and that a hyperbolic relation exists between water content and phenol oxidase.

\section{Phenolics for Carbon Storage}

Changes in the concentration, form, and decay rate of phenolics in response to climate can guide to better sequester 
TABLE 3: Effects of environmental changes on phenolics and decomposition.

\begin{tabular}{|c|c|c|c|c|}
\hline Environmental changes & $\begin{array}{l}\text { Phenolics } \\
\text { production }\end{array}$ & $\begin{array}{c}\text { Phenolics } \\
\text { degradation }\end{array}$ & Decomposition & References \\
\hline \multirow{13}{*}{$\mathrm{CO}_{2}$} & $+/-$ & & & {$[83]$} \\
\hline & + & & & {$[84]$} \\
\hline & $x$ & & & [101] \\
\hline & + & & & [102] \\
\hline & + & & & {$[103]$} \\
\hline & $+/ x$ & & & {$[104]$} \\
\hline & $\times$ & - & & {$[105]$} \\
\hline & + & & - & {$[58]$} \\
\hline & + & & & {$[82]$} \\
\hline & + & & & {$[90]$} \\
\hline & + & & & {$[81]$} \\
\hline & & + & & {$[86]$} \\
\hline & & + & + & [87] \\
\hline \multirow{6}{*}{ Warming } & - & & & {$[90]$} \\
\hline & $\times$ & & & {$[83]$} \\
\hline & & $\times$ & & {$[106]$} \\
\hline & $+1-$ & & & {$[107]$} \\
\hline & + & & & [89] \\
\hline & & - & & [108] \\
\hline \multirow{6}{*}{$\mathrm{N}$ deposition } & $x$ & $+1-$ & & {$[105]$} \\
\hline & + & & - & {$[58]$} \\
\hline & & & $+/-$ & {$[45]$} \\
\hline & $\times /-$ & & & {$[94]$} \\
\hline & $\times 1-$ & & & {$[92]$} \\
\hline & - & & & {$[93]$} \\
\hline \multirow{7}{*}{ Drought } & & + & + & {$[87]$} \\
\hline & - & & & [109] \\
\hline & & & - & [100] \\
\hline & & $x /-$ & - & {$[100]$} \\
\hline & + & & & [110] \\
\hline & & & + & [98] \\
\hline & & + & + & {$[99]$} \\
\hline \multirow{3}{*}{$\mathrm{CO}_{2} \times$ Warming } & $\times$ & & & {$[90]$} \\
\hline & $\times /-$ & & & {$[83]$} \\
\hline & & - & & {$[108]$} \\
\hline \multirow{3}{*}{$\mathrm{CO}_{2} \times \mathrm{N}$ deposition } & & - & & {$[111]$} \\
\hline & & - & & {$[105]$} \\
\hline & & - & & [58] \\
\hline $\mathrm{CO}_{2} \times$ Drought & & $x$ & & {$[87]$} \\
\hline Warming $\times \mathrm{N}$ deposition & - & & & {$[112]$} \\
\hline
\end{tabular}

+: stimulation, - : inhibition, and $\times$ : no effect or interaction.

terrestrial C. Recently, Freeman et al. [7] have proposed that enhanced carbon storage in ecosystems, particularly in peatlands, is feasible by modifying phenolic contents which inhibit decomposition of organic matter by a mechanism called "enzymic latch" $[113,114]$. They proposed that increases in phenolic content in peat ecosystems can be achieved either by increased expression of phenolic inhibitors from peatland plants or by enhancement of enzyme latch by physicochemical modification. Furthermore, it is widely known that phenolic content can be enhanced by modifying pyrolysis conditions such as temperature, pyrolysis time, substrate, and oxygen supply for biochar preparation [115]. As such, we 
propose that addition of biochar with high phenolics content represents a further approach to stabilize SOM in terrestrial ecosystems by inhibiting enzyme activities [116].

\section{Future Studies Suggested}

Studies of the ecological significance of phenolics have been conducted extensively since 1980, contributing significant understanding of their production, quantification, degradation, and effect on decomposition. As a secondary metabolite, phenolics have a range of structures and forms, with different reactivity. As such, application of appropriate methods for extraction and measurement must be applied according to the aims of each study. Assays to assess the activities of phenol oxidase and peroxidase have been developed to predict the degree and the direction of phenolic degradation.

However, there still remains controversy over how phenolics influence soil $\mathrm{C}$ cycling and how they are likely to respond to anticipated global environmental changes. For example, a larger supply of phenolics by global climate change may result in either faster or slower decomposition depending on the wider environmental conditions (Figure 3). Further, we conclude that the opposing trends of the effect of phenolics on SOM decomposition may be attributed to an insufficiently refined definition of the term "phenolics" or to the lack of information on redox mediators that control extracellular enzyme activities. We, therefore, propose that further studies are needed to understand fate of phenolics in response to simultaneous environmental changes with far higher resolution than in current practice. ${ }^{13} \mathrm{C}$ labeling may be an appropriate tool to elucidate phenolic turnover in soils. Additionally, molecular approaches aiming at specific genes for phenol degrading enzymes must be considered. Enhancing our knowledge about the role of phenolics following environmental change will facilitate a better understanding of nutrient dynamics in soils. Ultimately, such information can also be applied to techniques for carbon sequestration in terrestrial ecosystems by slowing down decomposition processes.

\section{Conflict of Interests}

The authors declare that there is no conflict of interests regarding the publication of this paper.

\section{Acknowledgment}

The authors would like to thank MinJung Kwon for reviewing the paper.

\section{References}

[1] S. Hättenschwiler and P. M. Vitousek, "The role of polyphenols in terrestrial ecosystem nutrient cycling," Trends in Ecology and Evolution, vol. 15, no. 6, pp. 238-242, 2000.

[2] C. Freeman, C. D. Evans, D. T. Monteith, B. Reynolds, and N. Fenner, "Export of organic carbon from peat soils," Nature, vol. 412, no. 6849, p. 785, 2001.
[3] P. Rovira and V. R. Vallejo, "Labile and recalcitrant pools of carbon and nitrogen in organic matter decomposing at different depths in soil: an acid hydrolysis approach," Geoderma, vol. 107, no. 1-2, pp. 109-141, 2002.

[4] H. Toberman, R. Laiho, C. D. Evans et al., "Long-term drainage for forestry inhibits extracellular phenol oxidase activity in Finnish boreal mire peat," European Journal of Soil Science, vol. 61, no. 6, pp. 950-957, 2010.

[5] J. P. Schimel, R. G. Cates, and R. Ruess, "The role of balsam poplar secondary chemicals in controlling soil nutrient dynamics through succession in the Alaskan taiga," Biogeochemistry, vol. 42, no. 1-2, pp. 221-234, 1998.

[6] T. E. C. Kraus, R. J. Zasoski, and R. A. Dahlgren, "Fertility and $\mathrm{pH}$ effects on polyphenol and condensed tannin concentrations in foliage and roots," Plant and Soil, vol. 262, no. 1-2, pp. 95-109, 2004.

[7] C. Freeman, N. Fenner, and A. H. Shirsat, "Peatland geoengineering: an alternative approach to terrestrial carbon sequestration," Philosophical Transactions of the Royal Society A, vol. 370, no. 1974, pp. 4404-4421, 2012.

[8] H. M. Appel, "Phenolics in ecological interactions: the importance of oxidation," Journal of Chemical Ecology, vol. 19, no. 7, pp. 1521-1552, 1993.

[9] T. E. C. Kraus, R. A. Dahlgren, and R. J. Zasoski, “Tannins in nutrient dynamics of forest ecosystems-a review," Plant and Soil, vol. 256, no. 1, pp. 41-66, 2003.

[10] R. G. Cates and D. F. Rhoades, "Patterns in the production of antiherbivore chemical defenses in plant communities," Biochemical Systematics and Ecology, vol. 5, no. 3, pp. 185-193, 1977.

[11] L. Bravo, "Polyphenols: chemistry, dietary sources, metabolism, and nutritional significance," Nutrition Reviews, vol. 56, no. 11, pp. 317-333, 1998.

[12] J. D. Box, "Investigation of the Folin-Ciocalteau phenol reagent for the determination of polyphenolic substances in natural waters," Water Research, vol. 17, no. 5, pp. 511-525, 1983.

[13] J. I. Hedges and J. R. Ertel, "Characterization of lignin by gas capillary chromatography of cupric oxide oxidation products," Analytical Chemistry, vol. 54, no. 2, pp. 174-178, 1982.

[14] W. Kelley, D. Coffey, and T. Mueller, "Liquid chromatographic determination of phenolic acids in soil," Journal of AOAC International, vol. 77, pp. 805-809, 1994.

[15] V. M. Hebatpuria, H. A. Arafat, H. S. Rho, P. L. Bishop, N. G. Pinto, and R. C. Buchanan, "Immobilization of phenol in cement-based solidified/stabilized hazardous wastes using regenerated activated carbon: leaching studies," Journal of Hazardous Materials, vol. 70, no. 3, pp. 117-138, 1999.

[16] M. W. I. Schmidt, M. S. Torn, S. Abiven et al., "Persistence of soil organic matter as an ecosystem property," Nature, vol. 478, no. 7367, pp. 49-56, 2011.

[17] R. T. Conant, M. G. Ryan, G. I. Ågren et al., “Temperature and soil organic matter decomposition rates-synthesis of current knowledge and a way forward," Global Change Biology, vol. 17, no. 11, pp. 3392-3404, 2011.

[18] J. A. J. Dungait, D. W. Hopkins, A. S. Gregory, and A. P. Whitmore, "Soil organic matter turnover is governed by accessibility not recalcitrance," Global Change Biology, vol. 18, no. 6, pp. 17811796, 2012.

[19] G. Gleixner, "Soil organic matter dynamics: a biological perspective derived from the use of compound-specific isotopes studies," Ecological Research, vol. 28, no. 5, pp. 683-695, 2013. 
[20] W. J. Parton, D. S. Schimel, C. V. Cole, and D. S. Ojima, "Analysis of factors controlling soil organic matter levels in Great Plains grasslands," Soil Science Society of America Journal, vol. 51, no. 5, pp. 1173-1179, 1987.

[21] U. Blum, "Benefits of citrate over EDTA for extracting phenolic acids from soils and plant debris," Journal of Chemical Ecology, vol. 23, no. 2, pp. 347-362, 1997.

[22] A. Arditsoglou and D. Voutsa, "Determination of phenolic and steroid endocrine disrupting compounds in environmental matrices," Environmental Science and Pollution Research, vol. 15, no. 3, pp. 228-236, 2008.

[23] S. Mukhopadhyay, D. L. Luhria, and R. J. Robbins, "Optimization of extraction process for phenolic acids from black cohosh (Cimicifuga racemosa) by pressurized liquid extraction," Journal of the Science of Food and Agriculture, vol. 86, no. 1, pp. 156-162, 2006.

[24] A. Pind, C. Freeman, and M. A. Lock, "Enzymic degradation of phenolic materials in peatlands-measurement of phenol oxidase activity," Plant and Soil, vol. 159, no. 2, pp. 227-231, 1994.

[25] M. Stursova and R. L. Sinsabaugh, "Stabilization of oxidative enzymes in desert soil may limit organic matter accumulation," Soil Biology and Biochemistry, vol. 40, no. 2, pp. 550-553, 2008.

[26] H. Kang, S.-H. Lee, S.-M. Lee, and S. Jung, "Positive relationships between phenol oxidase activity and extractable phenolics in estuarine soils," Chemistry and Ecology, vol. 25, no. 2, pp. 99$106,2009$.

[27] V. Thoss, A. Shevtsova, and M.-C. Nilsson, "Environmental manipulation treatment effects on the reactivity of watersoluble phenolics in a subalpine tundra ecosystem," Plant and Soil, vol. 259, no. 1-2, pp. 355-365, 2004.

[28] T. Ohno and P. R. First, "Assessment of the Folin and Ciocalteu's method for determining soil phenolic carbon," Journal of Environmental Quality, vol. 27, no. 4, pp. 776-782, 1998.

[29] P. J. Kersten, B. Kalyanaraman, K. E. Hammel, B. Reinhammar, and T. K. Kirk, "Comparison of lignin peroxidase, horseradish peroxidase and laccase in the oxidation of methoxybenzenes," Biochemical Journal, vol. 268, no. 2, pp. 475-480, 1990.

[30] S. R. Couto, D. Moldes, and M. A. Sanromán, "Optimum stability conditions of $\mathrm{pH}$ and temperature for ligninase and manganese-dependent peroxidase from Phanerochaete chrysosporium. Application to in vitro decolorization of Poly R478 by MnP," World Journal of Microbiology and Biotechnology, vol. 22, no. 6, pp. 607-612, 2006.

[31] I.-C. Kuan, K. A. Johnson, and M. Tien, "Kinetic analysis of manganese peroxidase. The reaction with manganese complexes," Journal of Biological Chemistry, vol. 268, no. 27, pp. 20064-20070, 1993.

[32] C. Ruttimann-Johnson, D. Cullen, and R. T. Lamar, "Manganese peroxidases of the white rot fungus Phanerochaete sordida," Applied and Environmental Microbiology, vol. 60, no. 2, pp. 599605, 1994.

[33] P. M. Coll, J. M. Fernandez-Abalos, J. R. Villanueva, R. Santamaria, and P. Perez, "Purification and characterization of a phenoloxidase (laccase) from the lignin-degrading basidiomycete PM1 (CECT 2971)," Applied and Environmental Microbiology, vol. 59, no. 8, pp. 2607-2613, 1993.

[34] D. Litthauer, M. J. van Vuuren, A. van Tonder, and F. W. Wolfaardt, "Purification and kinetics of a thermostable laccase from Pycnoporus sanguineus (SCC 108)," Enzyme and Microbial Technology, vol. 40, no. 4, pp. 563-568, 2007.

[35] T. Johjima, M. Ohkuma, and T. Kudo, "Isolation and cDNA cloning of novel hydrogen peroxide-dependent phenol oxidase from the basidiomycete Termitomyces albuminosus," Applied Microbiology and Biotechnology, vol. 61, no. 3, pp. 220-225, 2003.

[36] R. L. Prior, X. Wu, and K. Schaich, "Standardized methods for the determination of antioxidant capacity and phenolics in foods and dietary supplements," Journal of Agricultural and Food Chemistry, vol. 53, no. 10, pp. 4290-4302, 2005.

[37] R. Kiem and I. Kögel-Knabner, "Contribution of lignin and polysaccharides to the refractory carbon pool in C-depleted arable soils," Soil Biology and Biochemistry, vol. 35, no. 1, pp. 101$118,2003$.

[38] S. Theuerl, N. Dörr, G. Guggenberger et al., "Response of recalcitrant soil substances to reduced $\mathrm{N}$ deposition in a spruce forest soil: integrating laccase-encoding genes and lignin decomposition," FEMS Microbiology Ecology, vol. 73, no. 1, pp. 166-177, 2010.

[39] A. Otto and M. J. Simpson, "Evaluation of $\mathrm{CuO}$ oxidation parameters for determining the source and stage of lignin degradation in soil," Biogeochemistry, vol. 80, no. 2, pp. 121-142, 2006.

[40] T. S. Fukuji, F. G. Tonin, and M. F. M. Tavares, "Optimization of a method for determination of phenolic acids in exotic fruits by capillary electrophoresis," Journal of Pharmaceutical and Biomedical Analysis, vol. 51, no. 2, pp. 430-438, 2010.

[41] F. Bekkara, M. Jay, M. R. Viricel, and S. Rome, "Distribution of phenolic compounds within seed and seedlings of two Vicia faba cvs differing in their seed tannin content, and study of their seed and root phenolic exudations," Plant and Soil, vol. 203, no. 1, pp. 27-36, 1998.

[42] J. A. Schofield, A. E. Hagerman, and A. Harold, "Loss of tannins and other phenolics from: willow leaf litter," Journal of Chemical Ecology, vol. 24, no. 8, pp. 1409-1421, 1998.

[43] M. Sène, C. Gallet, and T. Doré, "Phenolic compounds in a Sahelian sorghum (Sorghum bicolor) genotype (CE145-66) and associated soils," Journal of Chemical Ecology, vol. 27, no. 1, pp. 81-92, 2001.

[44] A. Uzer, E. Ercag, H. Parlar, R. Apak, and H. Filik, "Spectrophotometric determination of 4,6-dinitro-o-cresol (DNOC) in soil and lemon juice," Analytica Chimica Acta, vol. 580, no. 1, pp. 83-90, 2006.

[45] R. L. Sinsabaugh, "Phenol oxidase, peroxidase and organic matter dynamics of soil," Soil Biology and Biochemistry, vol. 42, no. 3, pp. 391-404, 2010.

[46] R. L. Sinsabaugh, C. L. Lauber, M. N. Weintraub et al., "Stoichiometry of soil enzyme activity at global scale," Ecology Letters, vol. 11, no. 11, pp. 1252-1264, 2008.

[47] L. He, W. Xiang, and X. Sun, "Effects of temperature and water level changes on enzyme activities in two typical peatlands: implications for the responses of carbon cycling in peatland to global climate change," in Proceedings of the International Conference on Environmental Science and Information Application Technology (ESIAT '09), pp. 18-22, IEEE, Wuhan, China, July 2009.

[48] T. H. Bell and H. A. L. Henry, "Fine scale variability in soil extracellular enzyme activity is insensitive to rain events and temperature in a mesic system," Pedobiologia, vol. 54, no. 2, pp. 141-146, 2011.

[49] C. A. Lehmeier, K. Min, N. D. Niehues, F. Ballantyne, and S. A. Billings, "Temperature-mediated changes of exoenzymesubstrate reaction rates and their consequences for the carbon to nitrogen flow ratio of liberated resources," Soil Biology and Biochemistry, vol. 57, pp. 374-382, 2013. 
[50] N. Fenner, C. Freeman, and B. Reynolds, "Observations of a seasonally shifting thermal optimum in peatland carboncycling processes; implications for the global carbon cycle and soil enzyme methodologies," Soil Biology and Biochemistry, vol. 37, no. 10, pp. 1814-1821, 2005.

[51] H. Yao, D. Bowman, T. Rufty, and W. Shi, "Interactions between $\mathrm{N}$ fertilization, grass clipping addition and $\mathrm{pH}$ in turf ecosystems: implications for soil enzyme activities and organic matter decomposition," Soil Biology and Biochemistry, vol. 41, no. 7, pp. 1425-1432, 2009.

[52] M. P. Waldrop and D. R. Zak, "Response of oxidative enzyme activities to nitrogen deposition affects soil concentrations of dissolved organic carbon," Ecosystems, vol. 9, no. 6, pp. 921-933, 2006.

[53] M. P. Waldrop and J. W. Harden, "Interactive effects of wildfire and permafrost on microbial communities and soil processes in an Alaskan black spruce forest," Global Change Biology, vol. 14, no. 11, pp. 2591-2602, 2008.

[54] R. A. White, C. Freeman, and H. Kang, "Plant-derived phenolic compounds impair the remediation of acid mine drainage using treatment wetlands," Ecological Engineering, vol. 37, no. 2, pp. 172-175, 2011.

[55] G. D. Bending and D. J. Read, "Lignin and soluble phenolic degradation by ectomycorrhizal and ericoid mycorrhizal fungi," Mycological Research, vol. 101, no. 11, pp. 1348-1354, 1997.

[56] L. Tian, E. Dell, and W. Shi, "Chemical composition of dissolved organic matter in agroecosystems: correlations with soil enzyme activity and carbon and nitrogen mineralization," Applied Soil Ecology, vol. 46, no. 3, pp. 426-435, 2010.

[57] R. M. Burke and J. W. G. Cairney, "Laccases and other polyphenol oxidases in ecto- and ericoid mycorrhizal fungi," Mycorrhiza, vol. 12, no. 3, pp. 105-116, 2002.

[58] A. Siegenthaler, A. Buttler, L. Bragazza et al., "Litter- and ecosystem-driven decomposition under elevated $\mathrm{CO}_{2}$ and enhanced N deposition in a Sphagnum peatland," Soil Biology and Biochemistry, vol. 42, no. 6, pp. 968-977, 2010.

[59] J. M. Melillo, J. D. Aber, and J. F. Muratore, "Nitrogen and lignin control of hardwood leaf litter decomposition dynamics," Ecology, vol. 63, no. 3, pp. 621-626, 1982.

[60] R. Aerts and H. de Caluwe, "Nutritional and plant-mediated controls on leaf litter decomposition of Carex species," Ecology, vol. 78, no. 1, pp. 244-260, 1997.

[61] V. Nicolai, "Phenolic and mineral content of leaves influences decomposition in European forest ecosystems," Oecologia, vol. 75, no. 4, pp. 575-579, 1988.

[62] F. Bernhard-Reversat, G. Main, K. Holl, J. Loumeto, and J. Ngao, "Fast disappearance of the water-soluble phenolic fraction in eucalypt leaf litter during laboratory and field experiments," Applied Soil Ecology, vol. 23, no. 3, pp. 273-278, 2003.

[63] C. Rumpel, I. Kögel-Knabner, and F. Bruhn, "Vertical distribution, age, and chemical composition of organic carbon in two forest soils of different pedogenesis," Organic Geochemistry, vol. 33, no. 10, pp. 1131-1142, 2002.

[64] D. E. Stott, G. Kassim, W. M. Jarrell, J. P. Martin, and K. Haider, "Stabilization and incorporation into biomass of specific plant carbons during biodegradation in soil," Plant and Soil, vol. 70, no. 1, pp. 15-26, 1983.

[65] R. R. Northup, R. A. Dahlgren, and J. G. McColl, "Polyphenols as regulators of plant-litter-soil interactions in northern California's pygmy forest: a positive feedback?" Biogeochemistry, vol. 42, no. 1-2, pp. 189-220, 1998.
[66] F. Bernhard-Reversat, "Changes in relationships between initial litter quality and $\mathrm{CO}_{2}$ release during early laboratory decomposition of tropical leaf litters," European Journal of Soil Biology, vol. 34, no. 3, pp. 117-122, 1998.

[67] K. Opelt, V. Chobot, F. Hadacek, S. Schönmann, L. Eberl, and G. Berg, "Investigations of the structure and function of bacterial communities associated with Sphagnum mosses," Environmental Microbiology, vol. 9, no. 11, pp. 2795-2809, 2007.

[68] H. Mellegård, T. Stalheim, V. Hormazabal, P. E. Granum, and S. P. Hardy, "Antibacterial activity of sphagnum acid and other phenolic compounds found in Sphagnum papillosum against food-borne bacteria," Letters in Applied Microbiology, vol. 49, no. 1, pp. 85-90, 2009.

[69] C. Freeman, N. Fenner, N. J. Ostle et al., "Export of dissolved organic carbon from peatlands under elevated carbon dioxide levels," Nature, vol. 430, no. 6996, pp. 195-198, 2004.

[70] S. Minderlein and C. Blodau, "Humic-rich peat extracts inhibit sulfate reduction, methanogenesis, and anaerobic respiration but not acetogenesis in peat soils of a temperate bog," Soil Biology and Biochemistry, vol. 42, no. 12, pp. 2078-2086, 2010.

[71] R. R. Northup, Z. Yu, R. A. Dahlren, and K. A. Vogt, "Polyphenol control of nitrogen release from pine litter," Nature, vol. 377, no. 6546, pp. 227-229, 1995.

[72] E. T. Denisov and I. V. Khudyakov, "Mechanisms of action and reactivities of the free radicals of inhibitors," Chemical Reviews, vol. 87, no. 6, pp. 1313-1357, 1987.

[73] T. Stalheim, S. Ballance, B. E. Christensen, and P. E. Granum, "Sphagnan-A pectin-like polymer isolated from Sphagnum moss can inhibit the growth of some typical food spoilage and food poisoning bacteria by lowering the $\mathrm{pH}$," Journal of Applied Microbiology, vol. 106, no. 3, pp. 967-976, 2009.

[74] T. J. Painter, "Lindow man, tollund man and other peat-bog bodies: the preservative and antimicrobial action of Sphagnan, a reactive glycuronoglycan with tanning and sequestering properties," Carbohydrate Polymers, vol. 15, no. 2, pp. 123-142, 1991.

[75] R. G. Wetzel, "Gradient-dominated ecosystems: sources and regulatory functions of dissolved organic matter in freshwater ecosystems," Hydrobiologia, vol. 229, no. 1, pp. 181-198, 1992.

[76] N. Fierer, J. P. Schimel, R. G. Cates, and J. Zou, "Influence of balsam poplar tannin fractions on carbon and nitrogen dynamics in Alaskan taiga floodplain soils," Soil Biology and Biochemistry, vol. 33, no. 12-13, pp. 1827-1839, 2001.

[77] H. W. Müller, W. Trösch, and K. D. Kulbe, "Effect of phenolic compounds on cellulose degradation by some white rot basidiomycetes," FEMS Microbiology Letters, vol. 49, no. 1, pp. 87-93, 1988.

[78] Inderjit and A. U. Mallik, "Effect of phenolic compounds on selected soil properties," Forest Ecology and Management, vol. 92, no. 1-3, pp. 11-18, 1997.

[79] C. L. Meier and W. D. Bowman, "Phenolic-rich leaf carbon fractions differentially influence microbial respiration and plant growth," Oecologia, vol. 158, no. 1, pp. 95-107, 2008.

[80] M. J. Hoostal and J. L. Bouzat, "The modulating role of dissolved organic matter on spatial patterns of microbial metabolism in Lake Erie sediments," Microbial Ecology, vol. 55, no. 2, pp. 358368, 2008.

[81] J. Peñuelas and M. Estiarte, "Can elevated $\mathrm{CO}_{2}$ affect secondary metabolism and ecosystem function?" Trends in Ecology and Evolution, vol. 13, no. 1, pp. 20-24, 1998. 
[82] F. L. Booker and C. A. Maier, "Atmospheric carbon dioxide, irrigation, and fertilization effects on phenolic and nitrogen concentrations in loblolly pine (Pinus taeda) needles," Tree Physiology, vol. 21, no. 9, pp. 609-616, 2001.

[83] T. Räisänen, A. Ryyppö, R. Julkunen-Tiitto, and S. Kellomäki, "Effects of elevated $\mathrm{CO}_{2}$ and temperature on secondary compounds in the needles of Scots pine (Pinus sylvestris L.)," Trees, vol. 22, no. 1, pp. 121-135, 2008.

[84] A. Ghasemzadeh and H. Z. E. Jaafar, "Effect of $\mathrm{CO}_{2}$ enrichment on synthesis of some primary and secondary metabolites in ginger (Zingiber officinale Roscoe)," International Journal of Molecular Sciences, vol. 12, no. 2, pp. 1101-1114, 2011.

[85] S.-Y. Kim and H. Kang, "Effects of elevated $\mathrm{CO}_{2}$ on belowground processes in temperate marsh microcosms," Hydrobiologia, vol. 605, no. 1, pp. 123-130, 2008.

[86] X. Li, S. Han, Z. Guo, D. Shao, and L. Xin, "Changes in soil microbial biomass carbon and enzyme activities under elevated $\mathrm{CO}_{2}$ affect fine root decomposition processes in a Mongolian oak ecosystem," Soil Biology and Biochemistry, vol. 42, no. 7, pp. 1101-1107, 2010.

[87] T. Ellis, P. W. Hill, N. Fenner, G. G. Williams, D. Godbold, and C. Freeman, "The interactive effects of elevated carbon dioxide and water table draw-down on carbon cycling in a Welsh ombrotrophic bog," Ecological Engineering, vol. 35, no. 6, pp. 978-986, 2009.

[88] R. J. Norby, M. F. Cotrufo, P. Ineson, E. G. O’Neill, and J. G. Canadell, "Elevated $\mathrm{CO}_{2}$, litter chemistry, and decomposition: a synthesis," Oecologia, vol. 127, no. 2, pp. 153-165, 2001.

[89] W. Yi and H. Y. Wetzstein, "Biochemical, biological and histological evaluation of some culinary and medicinal herbs grown under greenhouse and field conditions," Journal of the Science of Food and Agriculture, vol. 90, no. 6, pp. 1063-1070, 2010.

[90] T. O. Veteli, W. J. Mattson, P. Niemelä et al., "Do elevated temperature and $\mathrm{CO}_{2}$ generally have counteracting effects on phenolic phytochemistry of boreal trees?" Journal of Chemical Ecology, vol. 33, no. 2, pp. 287-296, 2007.

[91] E. L. Zvereva and M. V. Kozlov, "Consequences of simultaneous elevation of carbon dioxide and temperature for plant-herbivore interactions: a metaanalysis," Global Change Biology, vol. 12, no. 1, pp. 27-41, 2006.

[92] J. Witzell and A. Shevtsova, "Nitrogen-induced changes in phenolics of Vaccinium myrtillus-implications for interaction with a parasitic fungus," Journal of Chemical Ecology, vol. 30, no. 10, pp. 1937-1956, 2004.

[93] A. Shevtsova, M.-C. Nilsson, C. Gallet, O. Zackrisson, and A. Jäderlund, "Effects of long-term alleviation of nutrient limitation on shoot growth and foliar phenolics of Empetrum hermaphroditum," Oikos, vol. 111, no. 3, pp. 445-458, 2005.

[94] L. Nybakken, O. Johansson, and K. Palmqvist, "Defensive compound concentration in boreal lichens in response to simulated nitrogen deposition," Global Change Biology, vol. 15, no. 9, pp. 2247-2260, 2009.

[95] M. P. Waldrop, D. R. Zak, R. L. Sinsabaugh, M. Gallo, and C. Lauber, "Nitrogen deposition modifies soil carbon storage through changes in microbial enzymatic activity," Ecological Applications, vol. 14, no. 4, pp. 1172-1177, 2004.

[96] L. Bragazza, C. Freeman, T. Jones et al., "Atmospheric nitrogen deposition promotes carbon loss from peat bogs," Proceedings of the National Academy of Sciences of the United States of America, vol. 103, no. 51, pp. 19386-19389, 2006.

[97] C. Freeman, G. Liska, N. J. Ostle, M. A. Lock, B. Reynolds, and J. Hudson, "Microbial activity and enzymic decomposition processes following peatland water table drawdown," Plant and Soil, vol. 180, no. 1, pp. 121-127, 1996.

[98] C. J. Williams, E. A. Shingara, and J. B. Yavitt, "Phenol oxidase activity in peatlands in New York state: response to summer drought and peat type," Wetlands, vol. 20, no. 2, pp. 416-421, 2000.

[99] N. Fenner, C. Freeman, and B. Reynolds, "Hydrological effects on the diversity of phenolic degrading bacteria in a peatland: implications for carbon cycling," Soil Biology and Biochemistry, vol. 37, no. 7, pp. 1277-1287, 2005.

[100] H. Toberman, C. Freeman, R. R. E. Artz, C. D. Evans, and N. Fenner, "Impeded drainage stimulates extracellular phenol oxidase activity in riparian peat cores," Soil Use and Management, vol. 24, no. 4, pp. 357-365, 2008.

[101] A. Matros, S. Amme, B. Kettig, G. H. Buck-Sorlin, U. Sonnewald, and H.-P. Mock, "Growth at elevated $\mathrm{CO}_{2}$ concentrations leads to modified profiles of secondary metabolites in tobacco cv. SamsunNN and to increased resistance against infection with potato virus Y," Plant, Cell and Environment, vol. 29, no. 1, pp. 126-137, 2006.

[102] W. J. Mattson, R. Julkunen-Tiitto, and D. A. Herms, " $\mathrm{CO}_{2}$ enrichment and carbon partitioning to phenolics: do plant responses accord better with the protein competition or the growth-differentiation balance models?" Oikos, vol. 111, no. 2, pp. 337-347, 2005.

[103] A. Bazin, M. Goverde, A. Erhardt, and J. A. Shykoff, "Influence of atmospheric carbon dioxide enrichment on induced response and growth compensation after herbivore damage in Lotus corniculatus," Ecological Entomology, vol. 27, no. 3, pp. 271278, 2002.

[104] R. L. Lindroth, B. J. Kopper, W. F. J. Parsons et al., "Consequences of elevated carbon dioxide and ozone for foliar chemical composition and dynamics in trembling aspen (Populus tremuloides) and paper birch (Betula papyrifera)," Environmental Pollution, vol. 115, no. 3, pp. 395-404, 2001.

[105] X. Feng, A. J. Simpson, W. H. Schlesinger, and M. J. Simpson, "Altered microbial community structure and organic matter composition under elevated $\mathrm{CO}_{2}$ and $\mathrm{N}$ fertilization in the duke forest," Global Change Biology, vol. 16, no. 7, pp. 2104-2116, 2010.

[106] T. H. Bell, J. N. Klironomos, and H. A. L. Henry, "Seasonal responses of extracellular enzyme activity and microbial biomass to warming and nitrogen addition," Soil Science Society of America Journal, vol. 74, no. 3, pp. 820-828, 2010.

[107] A. H. Hansen, S. Jonasson, A. Michelsen, and R. JulkunenTiitto, "Long-term experimental warming, shading and nutrient addition affect the concentration of phenolic compounds in arctic-alpine deciduous and evergreen dwarf shrubs," Oecologia, vol. 147, no. 1, pp. 1-11, 2006.

[108] N. Fenner, C. Freeman, M. A. Lock, H. Harmens, B. Reynolds, and T. Sparks, "Interactions between elevated $\mathrm{CO}_{2}$ and warming could amplify DOC exports from peatland catchments," Environmental Science and Technology, vol. 41, no. 9, pp. 3146-3152, 2007.

[109] M. Greven, S. Neal, S. Green, B. Dichio, and B. Clothier, "The effects of drought on the water use, fruit development and oil yield from young olive trees," Agricultural Water Management, vol. 96, no. 11, pp. 1525-1531, 2009.

[110] I. N. De Abreu and P. Mazzafera, "Effect of water and temperature stress on the content of active constituents of Hypericum brasiliense Choisy," Plant Physiology and Biochemistry, vol. 43, no. 3, pp. 241-248, 2005. 
[111] C. E. Coviella, R. D. Stipanovic, and J. T. Trumble, "Plant allocation to defensive compounds: Interactions between elevated $\mathrm{CO}_{2}$ and nitrogen in transgenic cotton plants," Journal of Experimental Botany, vol. 53, no. 367, pp. 323-331, 2002.

[112] L. Nybakken, K. Klanderud, and Ø. Totland, "Simulated environmental change has contrasting effects on defensive compound concentration in three alpine plant species," Arctic, Antarctic, and Alpine Research, vol. 40, no. 4, pp. 709-715, 2008.

[113] C. Freeman, N. Ostle, and H. Kang, "An enzymic 'latch' on a global carbon store: a shortage of oxygen locks up carbon in peatlands by restraining a single enzymes," Nature, vol. 409, no. 6817, p. 149, 2001.

[114] N. Fenner and C. Freeman, "Drought-induced carbon loss in peatlands," Nature Geoscience, vol. 4, no. 12, pp. 895-900, 2011.

[115] D. P. Cole, E. A. Smith, and Y. J. Lee, "High-resolution mass spectrometric characterization of molecules on biochar from pyrolysis and gasification of switchgrass," Energy \& Fuels, vol. 26, no. 6, pp. 3803-3809, 2012.

[116] G. Yoo and H. Kang, "Effects of biochar addition on greenhouse gas emissions and microbial responses in a short-term laboratory experiment," Journal of Environmental Quality, vol. 41, no. 4, pp. 1193-1202, 2012. 

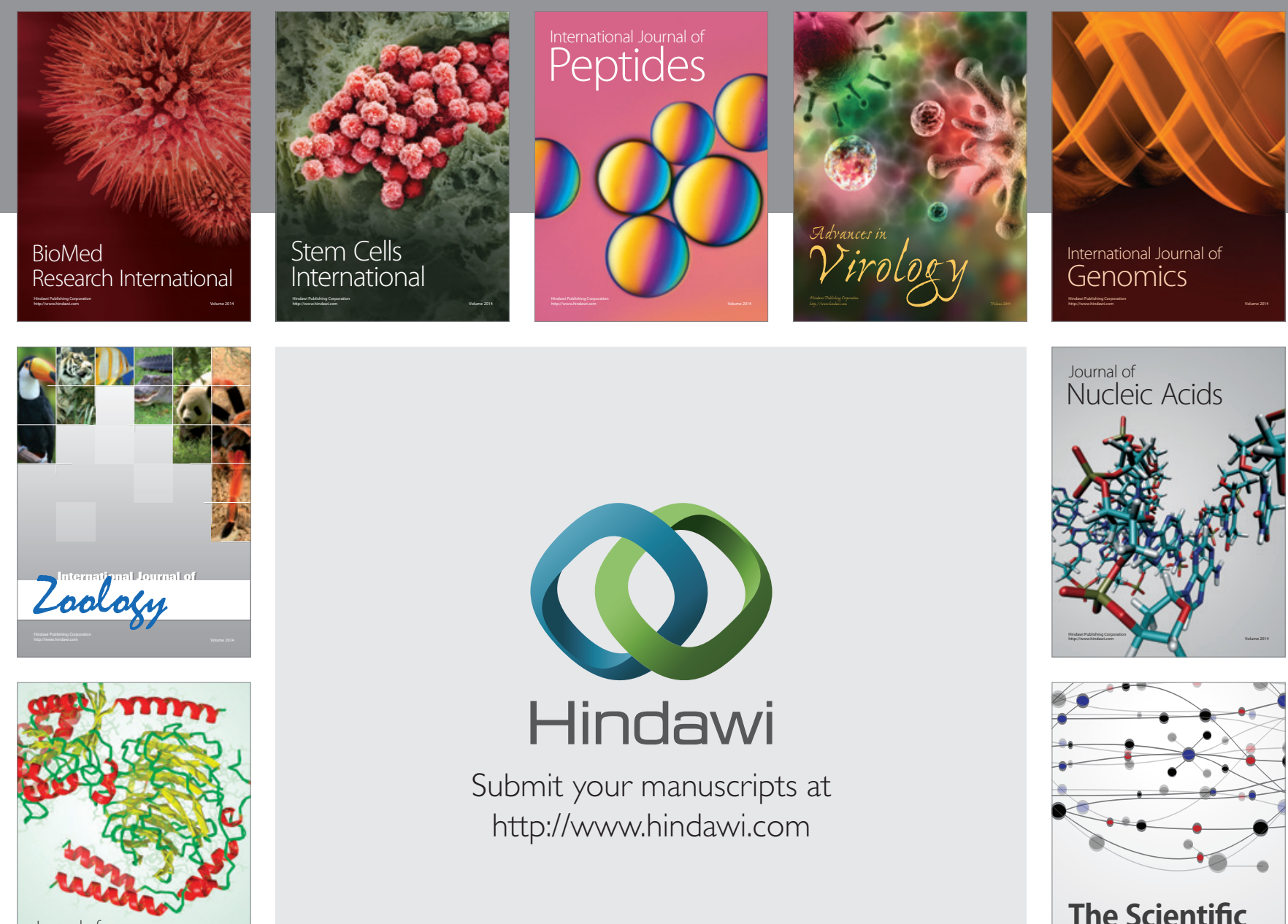

Submit your manuscripts at

http://www.hindawi.com

Journal of
Signal Transduction
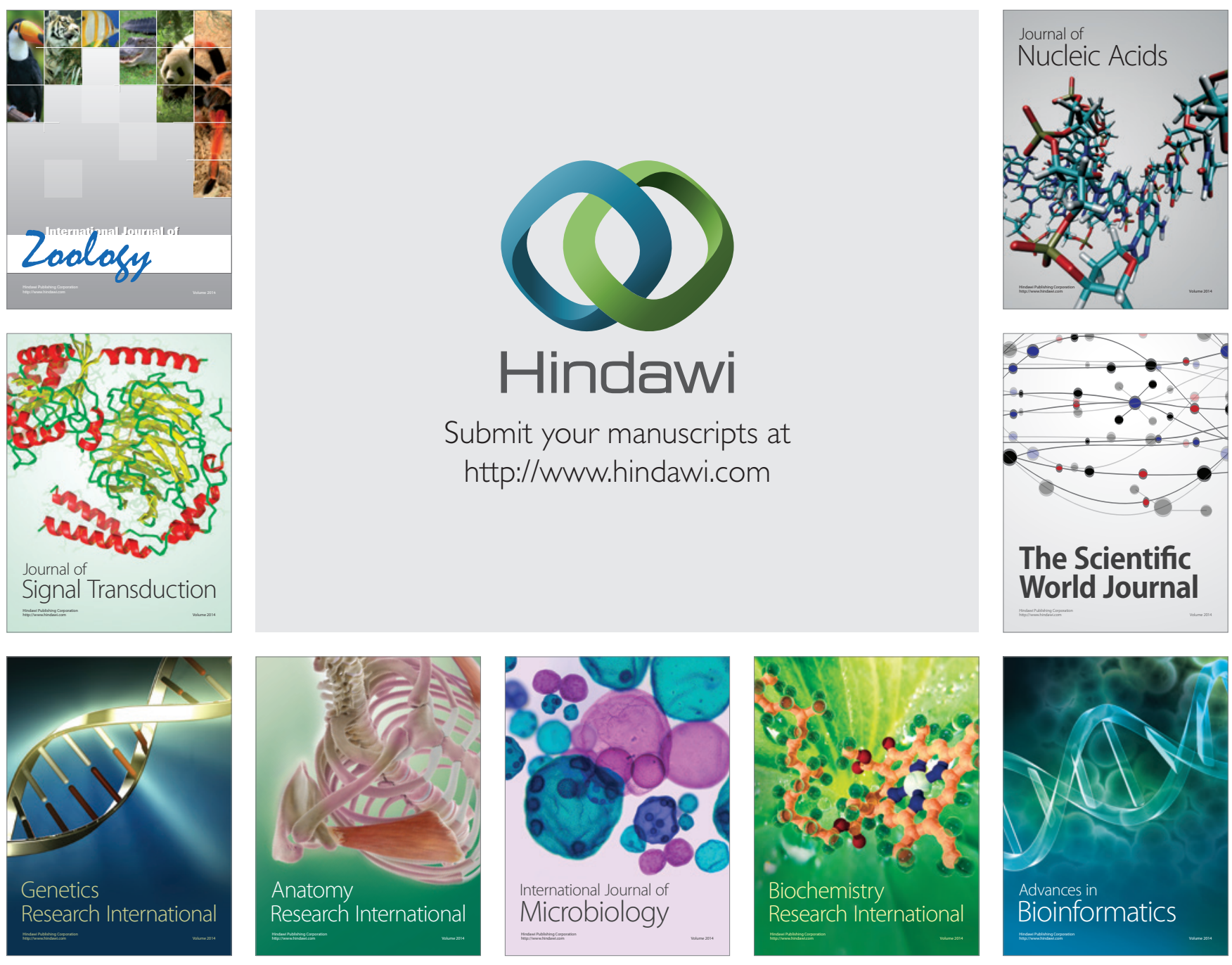

The Scientific World Journal
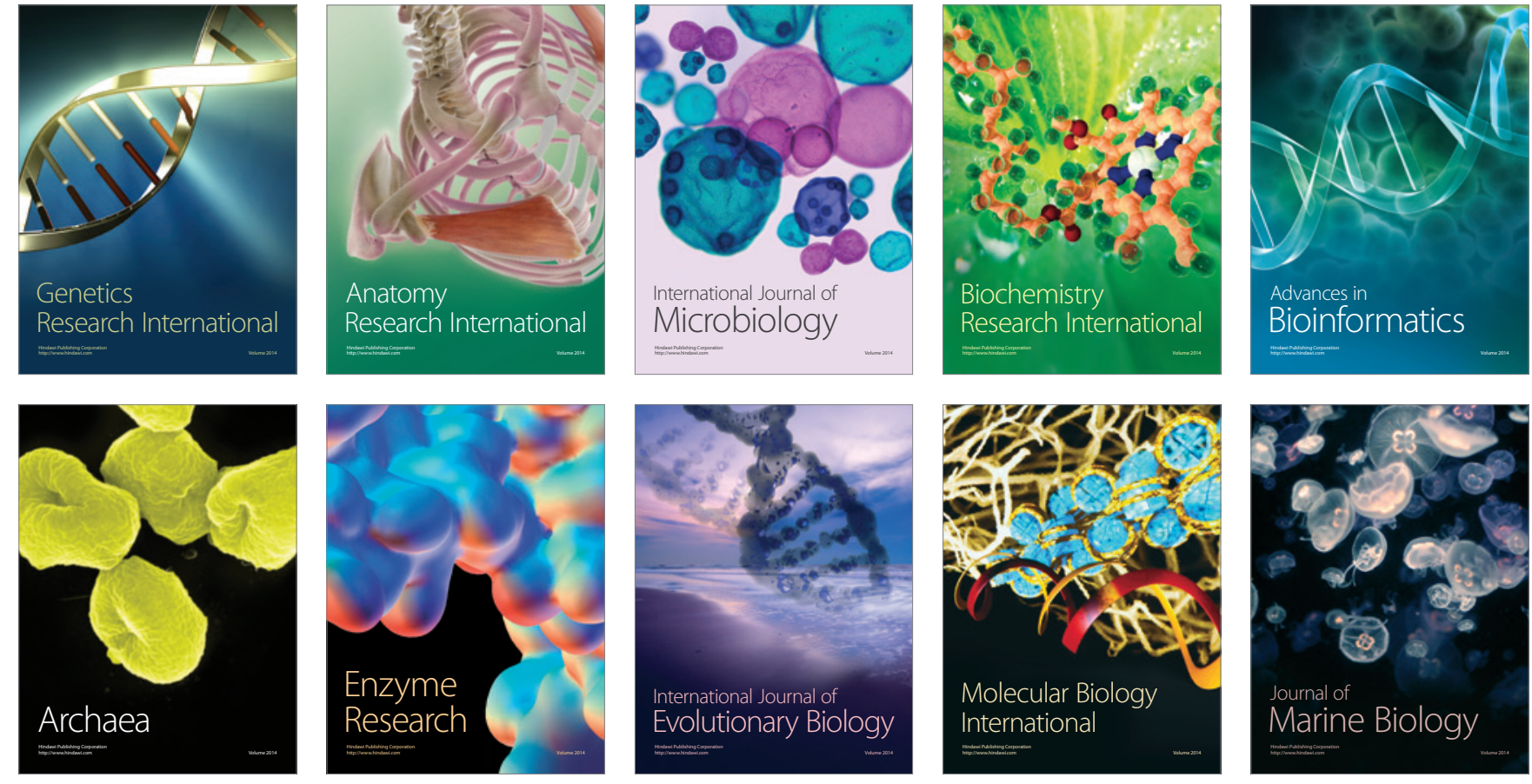